\title{
EFFECTS OF MODIFIED ATMOSPHERE PACKAGING ON RIPENING OF 'DOURADÃO' PEACH RELATED TO PECTOLYTIC ENZYMES ACTIVITIES AND CHILLING INJURY SYMPTOMS

\author{
LIGIA REGINA RADOMILLE DE SANTANA ${ }^{2 *}$, BENEDITO CARLOS BENEDETTI ${ }^{3}$, \\ JOSÉ MARIA MONTEIRO SIGRIST ${ }^{4}$, HÉLIA HARUMI SATO ${ }^{5}$
}

\begin{abstract}
The present study evaluated the effects of modified atmosphere packaging on inhibition of the development of chilling injury symptoms in 'Douradão' peach after cold storage and the possible involvement of cell wall enzymes. Fruits were harvested at the middle stadium of ripening, packed in polypropylene trays and placed inside low density polyethylene (LDPE) bags (30, 50, 60 and $75 \mu \mathrm{m}$ of thickness) with active modified atmosphere $\left(10 \mathrm{kPa} \mathrm{CO}+1.5 \mathrm{kPa} \mathrm{O}_{2}\right.$, balance $\left.\mathrm{N}_{2}\right)$. The following treatments were tested: Control: peaches held in nonwrapped trays; MA30: LDPE film - $30 \mu \mathrm{m} ;$ MA50: LDPE film - $50 \mu \mathrm{m} ;$ MA60: LDPE film - $60 \mu \mathrm{m}$ and MA75: LDPE film - $75 \mu \mathrm{m}$. Fruits were kept at $1 \pm 1{ }^{\circ} \mathrm{C}$ and $90 \pm 5 \%$ relative humidity (RH) for 28 days. After 14, 21 and 28 days, samples were withdrawn from MAP and kept in air at $25 \pm 1{ }^{\circ} \mathrm{C}$ and $90 \pm 5 \% \mathrm{RH}$ for ripening. On the day of removal and after 4 days, peaches were evaluated for woolliness incidence, pectolytic enzymes activities. The respiratory rate and ethylene synthesis were monitored during 6 days of ripening. The results showed that MA50 and MA60 treatments had positive effect on the inhibition of the development of woolly texture and reduced pectin methylesterase activity on the ripe fruits, keeping good quality of 'Douradão' peach during 28 days of cold storage. The treatments Control, MA30 and MA75 showed higher woolliness incidence and did not present marketable conditions after 14 days of cold storage. Index terms: Prunus persica, LDPE, woolliness, ethylene synthesis.
\end{abstract}

\section{EFEITOS DA EMBALAGEM SOB ATMOSFERA MODIFICADA NO AMADURECIMENTO DE PÊSSEGO 'DOURADÃO' RELATIVOS ÀS ATIVIDADES DAS ENZIMAS PECTINOLÍTICAS E SINTOMAS DE DANOS CAUSADOS PELO FRIO}

\begin{abstract}
RESUMO - O presente trabalho avaliou os efeitos da embalagem sob atmosfera modificada na inibição do desenvolvimento dos sintomas de danos causados pelo frio, em pêssego 'Douradão' após armazenamento refrigerado, e o possível envolvimento das enzimas da parede celular. Frutos foram colhidos no estádio médio de maturação, acondicionados em bandejas de polipropileno e colocados dentro de sacos de polietileno de baixa densidade (PEBD) com espessuras de 30; 50; 60 e $75 \mu \mathrm{m}$ e com modificação ativa da atmosfera (10 kPa $\mathrm{CO}_{2}+1,5 \mathrm{kPa} \mathrm{O}_{2}$, balanço de $\mathrm{N}_{2}$ ). Os seguintes tratamentos foram testados: Controle: pêssegos mantidos em bandejas sem filme plástico; AM30: filme de PEBD - $30 \mu \mathrm{m}$; AM50: filme de PEBD - $50 \mu \mathrm{m}$; AM60: filme de PEBD - $60 \mu \mathrm{m}$; $A M 75$ : filme de PEBD - $75 \mu \mathrm{m}$. Os frutos foram mantidos em câmara a $1 \pm 1{ }^{\circ} \mathrm{C}$ e $90 \pm 5 \%$ de umidade relativa (UR) por 28 dias. Após 14; 21 e 28 dias, as embalagens plásticas foram retiradas, e as amostras foram mantidas em ar a $25 \pm 1{ }^{\circ} \mathrm{C}$ e $90 \pm 5 \%$ UR para amadurecimento. No dia da remoção e após 4 dias, os pêssegos foram avaliados quanto à incidência de lanosidade, atividades das enzimas pectinolíticas. A taxa respiratória e a produção de etileno foram monitoradas durante 6 dias de amadurecimento. Os resultados mostraram que os tratamentos AM50 e AM60 tiveram efeito positivo na inibição do desenvolvimento de textura lanosa e reduziram a atividade da pectina metilesterase nos frutos maduros, mantendo a boa qualidade do pêssego 'Douradão' durante 28 dias de estocagem refrigerada. Os tratamentos Controle, AM30 e AM75 apresentaram maior incidência de lanosidade e não apresentaram condições de comercialização após 14 dias de armazenamento refrigerado.
\end{abstract}

Termos para indexação: Prunus persica, PEBD, lanosidade, síntese de etileno.

\footnotetext{
${ }^{1}$ (Trabalho 009-11). Recebido em:04-01-2011. Aceito para publicação em: 29-09-11. Parte do Projeto de Pesquisa "Conservação de pêssego cv. Dourado-2 sob atmosfera controlada", financiado pela FAPESP (Processo n.2006/03659-0).

${ }^{2}$ Prof ${ }^{a}$. Dra. Departamento Ciências da Vida, UNEB/Faculdade de Nutrição, Av. Silveira Martins, n.2555, 41195-001, Salvador-BA, Brasil, E-mail: ligiarrs@ig.com.br, lrsantana@uneb.br

${ }^{3}$ Prof. Dr. Faculdade de Engenharia Agrícola-UNICAMP, C.P. 6011, 13083-875, Campinas-SP, Brasil, E-mail: benedeti@agr.unicamp.br ${ }^{4}$ Pesquisador Dr. Grupo de Engenharia e Pós-colheita- ITAL, C.P. 130, 13001-970, Campinas-SP, Brasil, E-mail: jmms@ital.sp.gov.br ${ }^{5}$ Prof ${ }^{a}$. Dra. Faculdade de Engenharia de Alimentos- UNICAMP, C.P. 6121, 13083-862, Campinas-SP, Brasil, E-mail: heliah@fea.unicamp.br
} 


\section{INTRODUCTION}

Peaches 'Douradão' stored at low temperatures for prolonged periods can show a form of chilling injury called woolliness (mealiness), characterized by a lack of juiciness and a mealy texture (SANTANA et al., 2010). It is not possible to detect mealiness from the exterior of the fruit, since woolly fruit weigh is the same and they have a similar firmness to the fingers. However, when biting the fruit the lack of juice results in an absence of flavour and a dryness which make it inedible, and leads to consumer dissatisfaction. The woolliness in peach is caused by storage of fruit in the $2-8^{\circ} \mathrm{C}$ range for a period of at least 2 weeks (BEN-ARIE; LAVEE, 1971), and is of commercial importance due to the need to ship and store fruit prior to sale.

Numerous studies of the biochemical basis for woolliness have identified factors which may be important in the development of the symptoms, although considerable discrepancy exists between studies. Compared with juicy fruit, woolliness has been found to be associated with a reduction in pectin methylesterase (PME) activity (BUESCHER; FURMANSKI, 1978), or with an increase (BEN-ARIE; SONEGO, 1980), or with unchanged levels (OBENLAND; CARROLL, 2000; ZHOU et al., 2000b). Similarly, exopolygalacturonase (exo-PG) activity was reduced in mealy fruit in some studies (ZHOU et al., 2000b), or showed no correlation with mealiness in others (Artès et al., 1996). A reduction in endo-PG activity during cold storage has commonly been observed (BUESCHER; FURMANSKI, 1978; BEN-ARIE; SONEGO, 1980; ARTÈS et al., 1996; ZHOU et al., 2000b), although mealiness develops not in cold storage but during the subsequent ripening period at warm temperatures (BUESCHER; FURMANSKI, 1978). If the cold period exceeds a certain critical length (of approximately 2 weeks), or the ripening period is short, no increase in endo- PG activity occurs during ripening and, instead of juiciness, the fruit develop woolliness (BEN-ARIE; SONEGO, 1980; VON MOLLENDORFF; DE VILLIERS, 1988b). During the ripening period fruit may develop mealiness properties with low extractable juice, but upon extended ripening become juicy (VON MOLLENDORFF; DE VILLIERS, 1988b; VON MOLLENDORFF et al., 1989, 1993). However, this apparent restoration of free juice may be due to tissue breakdown and senescence processes. It has been suggested that changes to pectin metabolism cause mealiness either by cell fluids forming calciumpectate gel complexes with high molecular weight pectin in the middle lamella (BEN-ARIE ; LAVEE, 1971), or that the decreased intercellular adhesion in mealy fruit reduces cell rupture during biting and chewing, preventing the release of cellular contents (KING et al., 1989).

The development of woolliness symptoms is accompanied by reduced rates of respiration, very low ethylene evolution (VON MOLLENDORFF; DE VILLIERS, 1988A; ZHOU et al., 2001). These findings indicate that the normal metabolism associated with ripening is partially suspended. The synthesis of many cell-wall-modifying enzymes, including endo-PG and endo-1,4-ß-glucanase, is regulated by ethylene, although the accumulation of others such as PME may be controlled by different factors (BRUMMELL; HARPSTER, 2001). Brummell et al. (2004b) studied the cell wall metabolism during the development of chilling injury in cold storage peach fruit, plugs taken from fruit before a ripening period showed that, except for PME and endo-1,4ß-mannanase, increases in enzyme activity occurred between 1 and 2 weeks of cold storage if fruit would become juicy upon ripening, but that this increase was absent in fruit which would become mealy. After subsequent ripening, juicy fruit accumulated high levels of all enzymes examined, except for PME. The increase was greater after 1 week of storage for some enzymes, and after 2 weeks of storage for others. Since some enzymes increase during ripening and others increase then decrease (BRUMMELL et al., 2004a), the 'normal' activity of a particular enzyme is dependent on developmental stage. Juicy fruit thus retain the ability to synthesize or activate numerous enzymes both during cold storage and upon ripening, but this capacity is impaired in mealy fruit. Mealy fruit possessed low levels of all activities examined except exo-PG, but high levels of PME. The lack of correlation of exo-PG activity with mealiness (ARTÈS et al., 1996) and the decline then rise in PME activity with increasing cold storage (BEN-ARIE; LAVEE, 1971) are consistent with previous studies. The advanced stage of mealiness was correlated with low levels of endo-PG and high levels of PME activity (BEN-ARIE; LAVEE, 1971; BUESCHER; FURMANSKI, 1978; BEN-ARIE; SONEGO, 1980; VON MOLLENDORFF; DE VILLERS, 1988b; ARTÈS et al., 1996), but also with reduced activities of endo-1,4-ß-glucanase, endo-1,4-ß-mannanase, $\beta$-galactosidase and $\alpha$-arabinosidase. These observations suggest that cold storage causes a reduction in ethylene-regulated enzymes, including endo-PG, which are required for normal ripening in some peach varieties.

Reports have related that the use of modified 
atmosphere packaging (MAP) with elevated $\mathrm{CO}_{2}$ and reduced $\mathrm{O}_{2}$ concentrations delay or prevent the onset of these chilling symptoms and the storage life of peaches can be extended (LURIE; CRISOSTO, 2005; SANTANA et al. 2010). The aim of the present work was to study the responses of the 'Douradão' peach to low temperature storage and modified atmosphere packaging treatments in relation to cell wall modifying enzyme activities, the respiratory rate and ethylene synthesis. The effects of MAP in inhibition of the development of woolly texture in 'Douradão' peach and the possible involvement of cell wall enzymes were examined.

\section{MATERIALS AND METHODS}

Peaches (Prunus persica L.) 'Douradão’ were harvested from a commercial orchard in Jarinu, São Paulo, located in the southeast of Brazil under a subtropical climate, pre-selected and transported about $80 \mathrm{~km}$ to the Postharvest Laboratory. Then, the fruits were selected according to size and skin background color (green-yellow) at commercial maturity and immediately pre-cooled to $5^{\circ} \mathrm{C}$. Before pre-cooling, 72 peaches were randomly sampled and placed in 6 nonwrapped polypropylene (PP) trays (United Plastic Corporation S.A.), containing 12 peaches each, which were held in air at $25 \pm 1{ }^{\circ} \mathrm{C}$ and $90 \pm 5 \%$ RH during 4 days for ripening. On the same day of harvest ( 3 trays, each tray constituted a replicate) and on the $4^{\text {th }}$ day of ripening ( 3 trays), the peaches were evaluated for woolliness incidence, pectolytic enzymes activities: exo-polygalacturonase (exo-PG), endo-polygalacturonase (endo-PG) and pectin methylesterase (PME); the respiratory rate and ethylene synthesis were monitored during 6 days of ripening.

The experiment was carried out in an entirely randomized design where fruits to be cold stored were randomly distributed into five lots, one was held in non-wrapped PP trays (control) kept in air and the others were placed in similar PP trays, inserted in bags of low density polyethylene (LDPE) film (Altaplast Ltda, Brazil), where gas mixture of $10 \mathrm{kPa}$ $\mathrm{CO}_{2}+1.5 \mathrm{kPa} \mathrm{O}_{2}$ (balance $\mathrm{N}_{2}$ ) was injected and the packages were sealed, using a Selovac 200B machine (Selovac Ltda, Brazil). After sealing, the package area for gas exchange was equivalent to $0.21 \mathrm{~m}^{2} \mathrm{~kg}^{-1}$ of fruit. The following treatments were tested: Control: non-wrapped PP trays; $\boldsymbol{M A 3 0}$ : LDPE film of $30 \mu \mathrm{m}$ thickness, with $\mathrm{CO}_{2}$ permeability rate at standard temperature and pressure $\left(\mathrm{CO}_{2} \mathrm{PR}\right)$ of $22,021 \mathrm{~mL} \mathrm{~m}^{-2}$ $\mathrm{d}^{-1}$ and $\mathrm{O}_{2}$ permeability rate at standard temperature and pressure $\left(\mathrm{O}_{2} \mathrm{PR}\right)$ of $6,012 \mathrm{~mL} \mathrm{~m}^{-2} \mathrm{~d}^{-1}$, the water vapor permeability rate (WVPR) at $38^{\circ} \mathrm{C}$ and $90 \%$

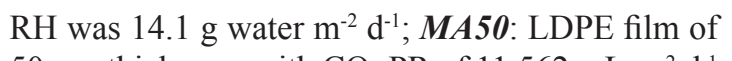
$50 \mu \mathrm{m}$ thickness, with $\mathrm{CO}_{2}$ PR of $11,562 \mathrm{~mL} \mathrm{~m}^{-2} \mathrm{~d}^{-1}$ and $\mathrm{O}_{2} \mathrm{PR}$ of 2,986 $\mathrm{mL} \mathrm{m}^{-2} \mathrm{~d}^{-1}$, the WVPR was 6.6 g water $\mathrm{m}^{-2} \mathrm{~d}^{-1}$; MA60: LDPE film of $60 \mu \mathrm{m}$ thickness, with $\mathrm{CO}_{2}$ PR of $9,577 \mathrm{~mL} \mathrm{~m}^{-2} \mathrm{~d}^{-1}$ and $\mathrm{O}_{2} \mathrm{PR}$

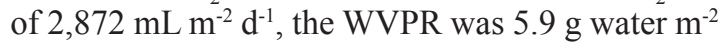
$\mathrm{d}^{-1} ; \boldsymbol{M A 7 5}$ : LDPE film of $75 \mu \mathrm{m}$ thickness, with $\mathrm{CO}_{2}$ PR of $7,425 \mathrm{~mL} \mathrm{~m}^{-2} \mathrm{~d}^{-1}$ and $\mathrm{O}_{2}$ PR of $1,705 \mathrm{~mL}$ $\mathrm{m}^{-2} \mathrm{~d}^{-1}$, the WVPR was $4.1 \mathrm{~g}$ water $\mathrm{m}^{-2} \mathrm{~d}^{-1}$. All treatments were stored during 28 days at $1 \pm 1{ }^{\circ} \mathrm{C}$ and $90 \pm 5 \%$ RH. After 14, 21 and 28 days, fruits were taken from cold storage, the LDPE films removed and subsequently the trays were held in air at $25 \pm 1^{\circ} \mathrm{C}$ and $90 \pm 5 \%$ RH during 4 days for ripening. On the same day of removal and on the $4^{\text {th }}$ day of ripening, peaches were evaluated as mentioned to the fruits at harvest. Three replicates per treatment were obtained to each assayed period (each tray with 12 peaches constituted a replicate).

At the same time of the ripening process, after harvest and after each cold storage period (14, 21 and 28 days), measurements of $\mathrm{CO}_{2}$ and $\mathrm{C}_{2} \mathrm{H}_{4}$ were carried out at $25 \pm 1^{\circ} \mathrm{C}$ and $90 \pm 5 \% \mathrm{RH}$ for 6 days. Three replicates of five fruits from each treatment were held in $2.5 \mathrm{~L}$ gastight jars, using a continuous humidified air flow of $2-3 \mathrm{~L} \mathrm{~h}^{-1}$ that passed through the jars (KADER, 2002; WATADA et al., 1996). The respiratory rate and ethylene emission were measured every day by taking 1 $\mathrm{mL}$ gas samples from the headspace and injecting in a gas chromatograph (Varian CG 3400, Varian Instruments, Walnut Creek, CA., USA). For $\mathrm{CO}_{2}$ determinations, the $\mathrm{CG}$ was equipped with a thermal conductivity detector $\left(200^{\circ} \mathrm{C}\right)$ and with a Molecular Sieve column (2.0 m length and $3.2 \mathrm{~mm}$ diameter, Norwalk, USA). Column and injector temperatures were $60^{\circ} \mathrm{C}$ and $70^{\circ} \mathrm{C}$, respectively. For ethylene, the $\mathrm{CG}$ was fitted with a flame ionization detector $\left(270^{\circ} \mathrm{C}\right)$ and with a Porapak N column $(4.0 \mathrm{~m}$ length and $3.2 \mathrm{~mm}$ diameter, Norwalk, USA), operating at $60^{\circ} \mathrm{C}$. Helium was used as carrier gas at $80 \mathrm{psi}$ and a flow rate of $30 \mathrm{~mL} \mathrm{~min}^{-1}$. Flame was obtained mixing hydrogen at $40 \mathrm{psi}$ and synthetic air at $60 \mathrm{psi}$, with flow rate of 70 and $300 \mathrm{~mL} \mathrm{~min}^{-1}$, respectively. Calibration of carbon dioxide, oxygen and ethylene was done with known standards (Air Liquide S.A., São Paulo, Brazil).

On each day of evaluation, ten fruits were randomly removed from three trays to determination of woolliness incidence (WI). The fruits were cut into two halves and the WI was determined visually in both sides (adapted from FERNÁNDEZ-TRUJILLO et al., 1998) and rated as very slight $(1 \%<$ area $\leq$ $10 \%)$, slight $(10 \%<$ area $\leq 25 \%)$, moderate $(25 \%<$ 
area $\leq 50 \%$ ) or severe (area $>50 \%$ ). Healthy fruits were those showing no signs of internal breakdown. The WI was calculated as follow: WI= (number of healthy fruit $\mathrm{x} 0)+($ number of fruits with very slight decay $x 1)+($ number of fruits with slight decay $x$ $2)+($ number of fruits with moderate decay $\times 3)+$ (number of fruits with severe decay $\mathrm{x} 4$ ), divided by $4 \times \mathrm{N}(\mathrm{N}=$ total number of fruits).

For the pectolytic enzymes activities assays, the peach flesh was macerated in a blender. The enzymes were extracted by homogenizing $100 \mathrm{~g}$ of peach flesh in $100 \mathrm{~mL}$ of cold aqueous solution containing polyethylene glycol 12\% (PEG 4000, Merck, Darmstadt, Germany) and $0.2 \%$ sodium bisulfite, during $2 \mathrm{~min}$. The homogenates were centrifuged (Beckman Centrifuge, Model J2-21, Beckman Instruments Inc., Palo Alto, CA., USA) at $10,000 \mathrm{x} g$ for $15 \mathrm{~min}$, the pellet was collected and separated into two parts for extraction of enzymes. For polygalacturonase (PG, EC 3.2.1.15) extraction, the pellet was incubated on a shaker (Marconi, Dubnoff mod. 145, Brazil) at $4{ }^{\circ} \mathrm{C}$ during $2 \mathrm{~h}$ in $80 \mathrm{~mL}$ of cold $50 \mathrm{mM} \mathrm{Na}$ acetate buffer (Merck, Brazil) pH 5.0 and $0.5 \mathrm{M} \mathrm{NaCl}$; after centrifugation as above, the supernatant was used as crude extract. For determination of the exo-PG activity, $1 \mathrm{~mL}$ extract was mixed with an equal volume of $2 \%$ polygalacturonic acid in $50 \mathrm{mM} \mathrm{Na}$ acetate buffer $\mathrm{pH} 4.4$ and incubated at $30^{\circ} \mathrm{C}$ for $18 \mathrm{~h}$. Reducing sugars released were determined with the Somogyi method (NELSON, 1944). Galacturonic acid was used as standard, and controls of boiled extract were run. One activity unit was defined as $1 \mu \mathrm{g}$ galacturonic acid released per $g$ of fresh sample per $\mathrm{h}$. The determination of the endo-PG activity was measured in a Cannon-Fenske viscosimeter (Model N.100, USA) by mixing $3 \mathrm{~mL}$ enzyme extract with $4.5 \mathrm{~mL} \mathrm{2 \%}$ polygalacturonic acid (Sigma Chemical Company, G-2125, USA) in $50 \mathrm{mM} \mathrm{Na}$ acetate $\mathrm{pH} 4.4$. Initial viscosity was measured and after a further $18 \mathrm{~h}$ incubation at $30^{\circ} \mathrm{C}$ (ZHOU et al., 2000a). One activity unit was defined as the change in viscosity (s) per $\mathrm{g}$ of fresh sample per h. For pectin methylesterase (PME, EC 3.1.1.11) extraction, the pellet was suspended in $50 \mathrm{~mL}$ of cold $7.5 \% \mathrm{NaCl}$ and $0.75 \%$ EDTA pH 6.5 solution, that was incubated on a shaker $4^{\circ} \mathrm{C}$ during $2 \mathrm{~h}$; after centrifugation the supernatant was collected to determinate PME activity. The extract was added to $1 \%$ citric pectin (Sigma Chemical Company, P-9135, USA) solution containing $0.2 \mathrm{~N} \mathrm{NaCl}, \mathrm{pH}$ adjusted to 7.4 with $0.1 \mathrm{~N} \mathrm{NaOH}$ and it was titrated (Mettler-Toledo titrator, DL50 Grafix, Columbus, OH., USA) to maintain $\mathrm{pH} 7.4$ during $30 \mathrm{~min}$, while incubated in a thermostatic bath (MLW, model U-2, Germany) at $30^{\circ} \mathrm{C}$ (ZHOU et al., 2000a). One unit activity was calculated as $1 \mu \mathrm{M} \mathrm{NaOH}$ consumed per $\mathrm{g}$ of fresh sample per $\mathrm{h}$.

An ANOVA for each parameter was performed using the $\mathrm{F}$ test and the treatment means were compared by the Tukey multiple range test at $p \leq 0.05$, using the SAS statistical package (SAS, 2003). The values at harvest and after each storage period were compared to find significant differences among treatments. The percentage data for the variable woolliness incidence were normalized according to the equation $f(x)=\operatorname{arcsen}(x+0.5)^{1 / 2}$.

\section{RESULTS AND DISCUSSION}

During ripening after harvest, it was observed an increase in the ethylene synthesis and respiration rate of the peaches (Figure 1). Accentuated ethylene production from the $3^{\text {th }}$ to $5^{\text {th }}$ day was concomitant with fruit ripening that showed typical behavior of climacteric fruit, and in this phase were initiated changes in color, aroma, texture, flavor and others biochemical and physiological attributes (SANTANA et al., 2010). After cold storage, changes in respiration rates and ethylene synthesis of peaches are showed in Figure 2 for all treatments during ripening at $25 \pm 1^{\circ} \mathrm{C}$. It was observed that the ethylene production and the respiration rate increased with the ripening. The Control and MA30 treatments showed a tendency of higher respiration rates while lower respiration rates were observed in fruits from MA50, MA60 and MA75 treatments. The respiration rate was around $95 \mathrm{mg}$ $\mathrm{CO}_{2} \mathrm{~kg}^{-1} \mathrm{~h}^{-1}$ at the beginning of the ripening process and increased to $120-130 \mathrm{mg} \mathrm{CO} \mathrm{kg}^{-1} \mathrm{~h}^{-1}$ during ripening, for the Control and MA30 treatments, while the others treatments reached respiration rates around to $100-110 \mathrm{mg} \mathrm{CO}_{2} \mathrm{~kg}^{-1} \mathrm{~h}^{-1}$ during ripening process. Similar tendencies were obtained with nectarines 'Fantasia' and 'Fairlane' and peaches 'Flavorcrest' and 'Red Top', where higher respiration rates during shelf-life were verified in the control treatment and lower respiration rates were obtained in polyethylene packages treatments (ZOFFOLi et al., 1998; AKBUDAK ; ERIS, 2004). Large increases in ethylene production were observed in Control and MA30 treatments. The ethylene emission was around $20 \mu \mathrm{L}$ $\mathrm{C}_{2} \mathrm{H}_{4} \mathrm{~kg}^{-1} \mathrm{~h}^{-1}$ at the beginning of the ripening process and increased to $50-70 \mu \mathrm{L} \mathrm{C} \mathrm{C}_{2} \mathrm{H}_{4} \mathrm{~kg}^{-1} \mathrm{~h}^{-1}$ until the $4^{\text {th }}$ ripening day, for the Control and MA30 treatments. This positive feed-back loop was interrupted and at $5^{\text {th }}$ and $6^{\text {th }}$ days began the senescence phase. The lowest ethylene production was observed in fruit from MA75 treatment, which produced about 7-10 $\mu \mathrm{L} \mathrm{C}_{2} \mathrm{H}_{4} \mathrm{~kg}^{-1} \mathrm{~h}^{-1}$ at the beginning of the ripening and reaching only 20-25 $\mu \mathrm{L} \mathrm{C}_{2} \mathrm{H}_{4} \mathrm{~kg}^{-1} \mathrm{~h}^{-1}$ on the $4^{\text {th }}$ ripening day; physiological 
alterations (fermented fruit) and senescence were verified in this treatment. Fruits from MA50 and MA60 produced around $12-15 \mu \mathrm{LC}_{2} \mathrm{H}_{4} \mathrm{~kg}^{-1} \mathrm{~h}^{-1}$ at the beginning of the ripening and an increased to $40-45 \mu \mathrm{L}$ $\mathrm{C}_{2} \mathrm{H}_{4} \mathrm{~kg}^{-1} \mathrm{~h}^{-1}$ until the $6^{\text {th }}$ ripening day was observed, remaining stable and keeping good quality of the fruits. Some reports (FERNÁNDEZ-TRUJILLO et al., 1998; GIRARDI et al., 2005) associated the higher incidence of woolliness with a sharp decrease in ethylene production rather than with a high respiratory rate during post-storage ripening. In this study, such behavior might be associated with the reduced occurrence of woolliness in MA50 and MA60 treatments and higher incidence of mealy texture in Control and MA30 treatments.

Figure 3 shows that woolliness incidence of 'Douradão' peach was affected by the MAP treatments. The Control, MA30 and MA75 treatments presented higher woolliness incidence after cold storage and post-storage ripening, independently of the period. Several studies about woolliness in peaches and nectarines reported that this condition became apparent by the time the fruits were removed from cold storage and kept at $20-25^{\circ} \mathrm{C}$ (CRISOSTO et al., 1999; ZHOU et al., 2000b; ROMBALDI et al., 2001). The use of MAP reduced the occurrence of woolliness, fruits from MA50 and MA60 treatments were little affected, reaching lower woolliness incidence after 28 days of cold storage.

In the fruit evaluated immediately after harvest, it was observed a gradual increase in the endo-PG and exo-PG activities during ripening, while the PME activity showed accentuated decrease during ripening (Figures 4, 5 and 6). In cold storage fruits were not found significant difference in the exo-PG activity among the treatments, independently of the storage period. With post-storage ripening was observed increase in exo-PG activity for all treatments, and were not found significant difference among the treatments, although these values had been always lower than the fruit evaluated after harvest (Figure 4). The association of exo-PG activity in the development of woolliness symptoms has showed many discrepancies. By some authors (ZHOU et al., 2000b; GIRARDI et al., 2005) the exo-PG activity was mentioned like reduced activity in woolly fruit, by others authors (VON MOLLENDORFF; DE VILLIERS, 1988b) peaches that developed woolliness during ripening showed increase on exo-PG activity and others studies related that there was no relation with woolliness symptoms (ARTÈS et al., 1996; BRUMMELL et al., 2004b). The endo-PG activity during 28 days of cold storage showed no significant difference among treatments (Figure 5). After additional 4 days ripening, was detected increase in endo-PG activity for all treatments, Control and the fruits from MA30 and MA75 treatments showed slight increase and no difference among each other was verified. The most significant increase was observed in fruits from MA50 and MA60 treatments, and these values were similar to that fruits evaluated after harvest. In these fruits the increase in ethylene production after $4^{\text {th }}$ day of ripening was followed by a concomitant increase in endo-PG activity, while the decline in ethylene production in Control was followed by a little increase in endo-PG activity. The PME activity from Control, MA30 and MA75 treatments were higher than the PME activity from MA50 and MA60 treatments, after cold storage and ripening post-storage. The PME activity of MA50 and MA60 treatments did not differ from fruits evaluated after harvest (Figure 6). It was observed that woolliness in 'Douradão' peaches is related to the low endo-PG and high PME activities. Previous reports (BENARIE; SONEGO, 1980; VON MOLLENDORFF; DE VILLIERS, 1988B; ZHOU et al., 2000b; Girardi et al., 2005) associated the incidence of woolliness in peaches with an imbalance between the PG and PME activities.

In this study, the rate between PG and PME activities (exo-PG/PME and endo-PG/PME) were calculated to found values that could explain the imbalance between the PG and PME in the woolly fruits. Fruits from MA50 and MA60 treatments showed higher rate between exo-PG/PME and endo-PG/PME after ripening at $25^{\circ} \mathrm{C}$, while Control, MA30 and MA75 treatments showed lower rate between exo-PG/ PME and endo-PG/PME (Table 1). Higher rate PG/ PME implied lower woolliness incidence in the fruits. When occur woolliness incidence, the polygalacturonic acid (main component of pectin) shows reduced methylation (due to higher PME activity), without subsequently degradation of pectin (due to lower PG activity), resulting large pectin molecules with reduced methylation that gelling and can cause more free water to be bound into gel, leading to less juice content and causing woolly texture (LURIE; CRISOSTO, 2005). Similar results were reported by ZHOU et al. (2000b), in their studies with 'Flavortop' nectarines cold stored under controlled atmosphere $\left(10 \% \mathrm{CO}_{2}\right.$ and $\left.3 \% \mathrm{O}_{2}\right)$ during 4 and 6 weeks. The authors also found lower rate between endo and exo-PG/PME to the Control fruit after 5 days at $20^{\circ} \mathrm{C}$, and higher rate between endo and exo-PG/PME to the fruits from CA storage. About the imbalance, they mentioned that there was no difference in the RNAm expression of the PG and PME enzymes, among Control fruit and those cold stored fruit under AC. The authors concluded that CA repress enzymes activities (mainly PG), but maintain the ability for recuperation of this repression, when the fruit are exposed on warmer temperatures. 


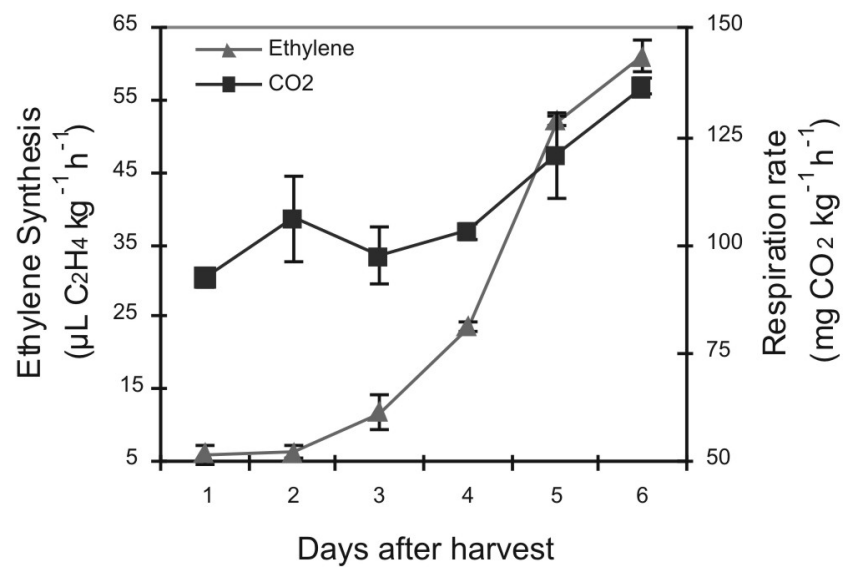

FIGURE 1 - Respiration rate and ethylene synthesis of 'Douradão' peaches during ripening at $25 \pm 1^{\circ} \mathrm{C}$ for 6 days, immediately after harvest. Standard deviation represented by the vertical bar $(n=3)$.

TABLE 1 - Rate between exo-PG and PME (exo-PG/PME) activities and endo-PG and PME (endo-PG/ PME) activities of 'Douradão' peaches cold storage (CS) at $1 \pm 1^{\circ} \mathrm{C}$ under MAP after 14, 21 and 28 days, plus 4 days ripening in air at $25 \pm 1^{\circ} \mathrm{C}$.

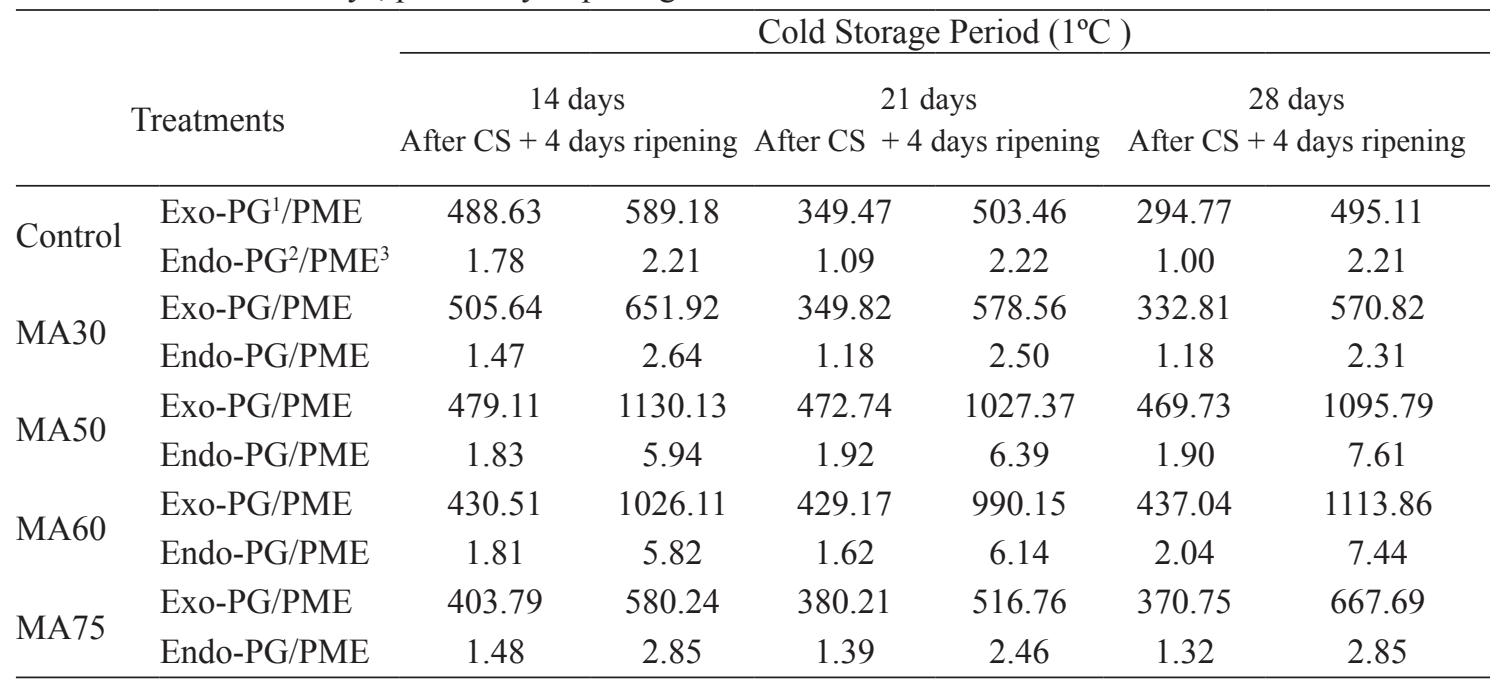

${ }^{1}$ One unit of Exo-PG was defined as $1 \mu \mathrm{g}$ galacturonic acid $\mathrm{g}^{-1}$ sample $^{-1}$.

${ }^{2}$ One unit of Endo-PG was defined as change in viscosity (s) $\mathrm{g}^{-1}$ sample $\mathrm{h}^{-1}$.

${ }^{3}$ One unit of PME was defined as $1 \mu \mathrm{M} \mathrm{NaOH} \mathrm{g}{ }^{-1}$ sample $\mathrm{h}^{-1}$. 

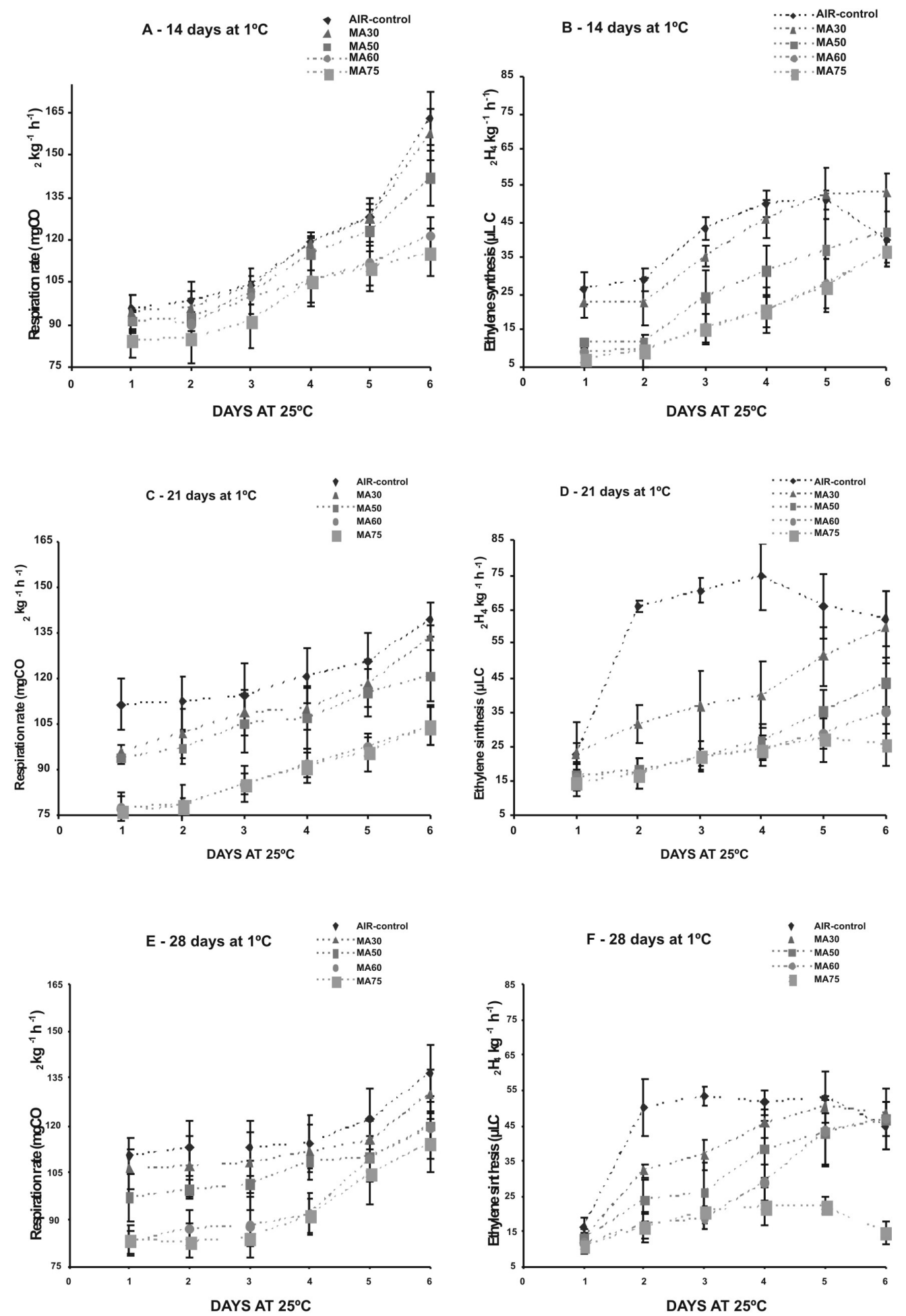

FIGURE 2 - Respiratory rate (A, C, E) and ethylene synthesis (B, D, F) of 'Douradão' peaches after 14, 21 and 28 days of cold storage under modified atmosphere (MAP) and ripening at $25 \pm 1^{\circ} \mathrm{C}$ for 6 days. Standard deviation represented by the vertical bar $(n=3)$. 


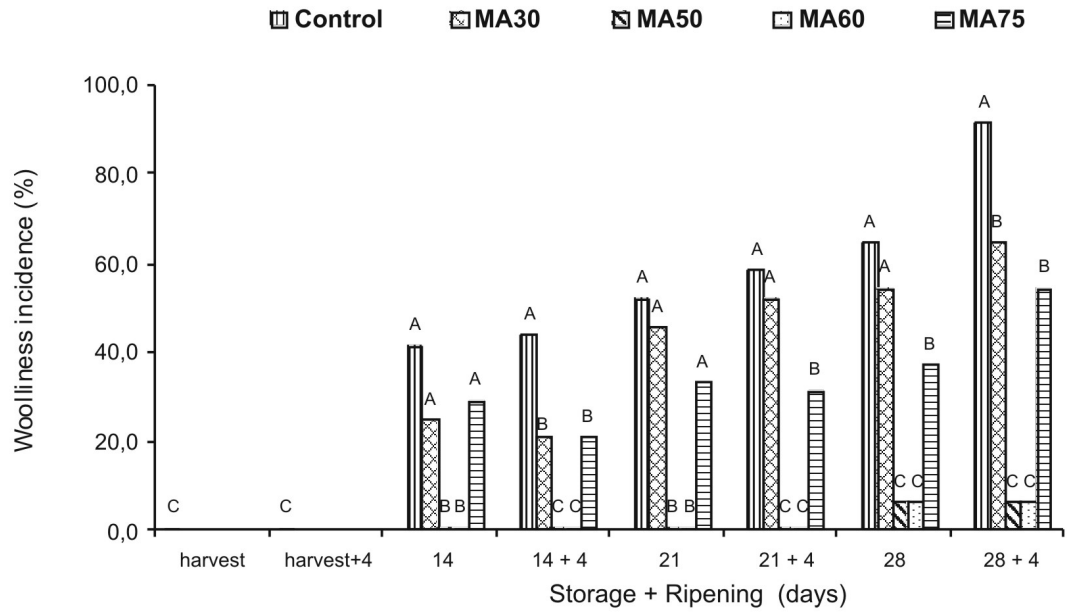

FIGURE 3 - Woolliness incidence of 'Douradão' peaches cold storage at $1 \pm 1^{\circ} \mathrm{C}$ under MAP after 14, 21 and 28 days, plus 4 days ripening in air at $25 \pm 1^{\circ} \mathrm{C}$.

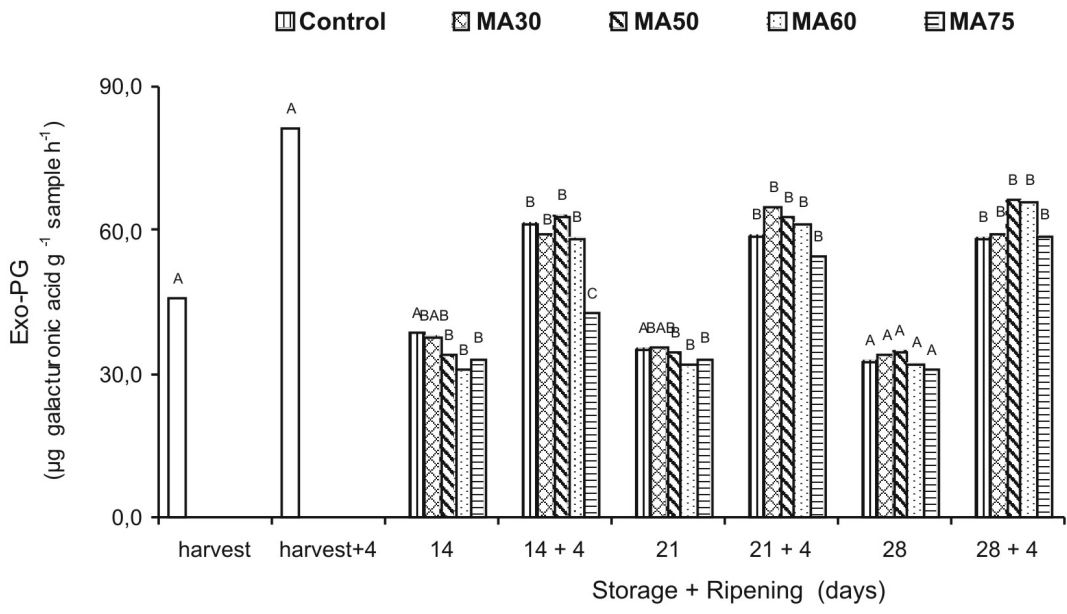

FIGURE 4 - Exo-Polygalacturonase activity of 'Douradão' peaches cold storage at $1 \pm 1^{\circ} \mathrm{C}$ under MAP after 14,21 and 28 days, plus 4 days ripening in air at $25 \pm 1^{\circ} \mathrm{C}$.

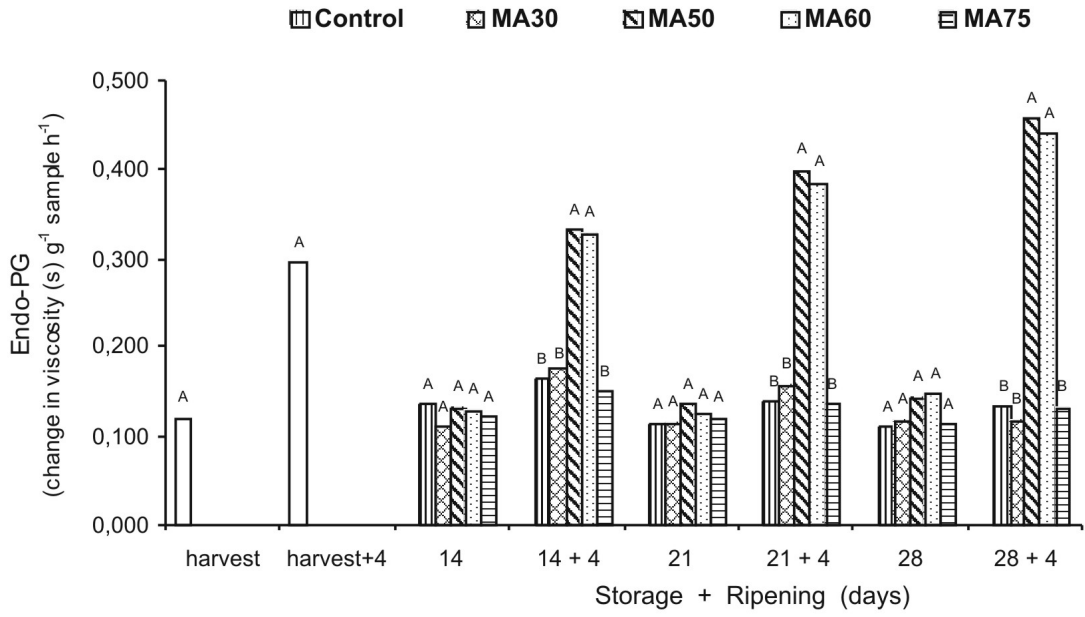

FIGURE 5 - Endo-Polygalacturonase activity of 'Douradão' peaches cold storage at $1 \pm 1^{\circ} \mathrm{C}$ under MAP after 14, 21 and 28 days, plus 4 days ripening in air at $25 \pm 1^{\circ} \mathrm{C}$. 




FIGURE 6 -Pectin methylesterase activity of 'Douradão' peaches cold storage at $1 \pm 1^{\circ} \mathrm{C}$ under MAP after 14,21 and 28 days, plus 4 days ripening in air at $25 \pm 1^{\circ} \mathrm{C}$.

\section{CONCLUSIONS}

1-Higher respiratory rate and ethylene production were verified in Control treatment and lower respiratory rate and ethylene production were obtained in MAP treatments.

2-Higher rate PG/PME implied lower woolliness incidence in the ripe fruits.

3-The MA50 and MA60 treatments had positive effect on the inhibition of the development of woolly texture, on the reduction the pectin methylesterase activity on the ripe fruits, keeping good quality of 'Douradão' peach during 28 days of cold storage.

4-The treatments Control, MA30 and MA75 showed higher woolliness incidence and did not present marketable conditions after 14 days of cold storage.

\section{REFERENCES}

AKBUDAK, B.; ERIS, A. Physical and chemical changes in peaches and nectarines during the modified atmosphere storage. Food Control, Oxford, v. 15, n. 2, p. 307-313, 2004.

ARTÈS, F.; CANO, A.; FERNÁNDEZ-TRUJILLO, J.P. Pectolytic enzyme activity during intermittent warming storage of peaches. Journal of Food Science, Washington, v. 61, n. 1, p. 311-321, 1996.
BEN-ARIE, R.; LAVEE, S. Pectic changes occuring in Elberta peaches suffering from woolly breakdown. Phytochemistry, Oxford, v.10, n. 1, p. 531-538, 1971.

BEN-ARIE, R.; SONEGO, L. Pectolytic enzyme activity involved in woolly breakdown of stored peaches. Phytochemistry, Oxford, v.19, n. 9, p. 2553-2555, 1980.

BRUMMELL, D.A.; DAL CIN, V.; CRISOSTO, C.H.; LABAVITCH, J.M. Cell wall metabolism during maturation, ripening and senescence of peach fruit. Journal of Experimental Botany, Oxford, v. 55, n. 405, p. 2029-2039, 2004a.

BRUMMELL, D.A.; DAL CIN, V.; LURIE, S.; CRISOSTO, C.H.; LABAVITCH, J.M. Cell wall metabolism during the development of chilling injury in cold-stored peach fruit: association of mealiness with arrested disassembly of cell wall pectins. Journal of Experimental Botany, Oxford, v. 55, n. 405, p. 2041-2052, 2004b.

BRUMMELL D.A.; HARPSTER M.H. Cell wall metabolism in fruit softening and quality and its manipulation in transgenic plants. Plant Molecular Biology, Oxford, v. 47, n. 101, p. 311-340, 2001.

BUESCHER, R.; FURMANSKI, R.J. Role the pectinesterase and polygalacturonase in the formation of woolliness in peaches. Journal of Food Science, Washington, v. 43, n. 1, p. 264-266, 1978. 
CRisosto, C.H.; MitChelL, F.G.; JU, Z. Susceptibility to chilling injury of peach, nectarine and plum cultivars grown in California. HortScience, Alexandria, v. 34, n. 1, p. 1116-1118, 1999.

FERNÁNDEZ-TRUJILLO, J.P.; CANO, A.; ARTÉS, F. Physiological changes in peaches related to chilling injury and ripening. Postharvest Biology and Technology, Wageningen, v. 13, n.1, p. 109119, 1998.

GIRARDI, C.L.; CORRENT, A.R.; LUCCHETTA, L.; ZANUZO, M.R.; COSTA, T.S.; BRACKMANN, A.; TWYMAN, R.M.; NORA, L.; SILVA, J.A.; ROMBALDI, C.V. Effect of ethylene, intermittent warming and controlled atmosphere on postharvest quality and the occurrence of woolliness in peach (Prunus persica cv. Chiripá) during cold storage. Postharvest Biology and Technology, Wageningen, v. 38, n. 1, p. 25-33, 2005.

KADER, A.A.; Methods of gas mixing, sampling and analysis. In: KADER, A.A.(Ed.). Postharvest technology of horticultural crops. Berkeley: University of California, 2002. p.145-148. (Publications, 3311)

KING, G.A.; HENDERSON, K.G.; LILL, R.E. Ultrastructural changes in the nectarine cell wall accompanying ripening and storage in a chillingresistant and chilling-sensitive cultivar. New Zealand Journal of Crop and Horticultural Science, Wellington, v.17, n. 2, p. 337-344, 1989.

LURIE, S.; CRISOTO, C.H. Chilling injury in peach and nectarine. Postharvest Biology and Technology, Wageningen, v. 37, n.1, p. 195-208, 2005.

NELSON, N.A. A photometric adaptation of Somogyi method for the determination of glucose. The Journal of Biological Chemistry, Oxford, v.135, n.1, p.136-137, 1944.

OBENLAND, D.M.; CARROLL, T.R. Mealiness and pectolytic activity in peaches and nectarines in response to heat treatment and cold storage. Journal of the American Society for Horticultural Science, Alexandria, v. 125, n.1, p. 723-728, 2000.
ROMBALDI, C.V.; SILVA, J.A.; MACHADO, L.B.; PARUSSOLO, A.; KASTER, L.C.; GIRARDI, C.L.; DANIELI, R. Harvesting stage and cold storage influences on the quality of Chiripá peaches (Prunus persica L). Ciência Rural, Santa Maria, v. 31, n. 2, p. 19-25, 2001.

SANTANA, L.R.R.; BENEDETTI, B.C.; SIGRIST, J.M.M. Sensory characteristics of 'Douradão' peaches submitted to modified atmosphere packaging. Revista Brasileira de Fruticultura, Jaboticabal, v. 32, n.3, p. 700-708, 2010.

SAS - Statistical Analysis System. User's procedures guide. Version 6. Cary, 2003. 2v.

VON MOLLENDORFF, L.J.; DE VILLIERS, O.T. Physiological changes associated with the development of woolliness in "Peregrine" peaches during low-temperature storage. Journal of Horticultural Science, Ashford, v. 63, n. 1, p. 4751, 1988a.

VON MOLLENDORFF, L.J.; DE VILLIERS, O.T. Role of pectolytic enzymes in the development of woolliness in peaches. Journal of Horticultural Science, Ashford, v.63, n.1, p. 53-58, 1988 b.

VON MOLLENDORFF, L.J.; DE VILLIERS, O.T.; JACOBS, G. Effect of time of examination and ripening temperature on the degree of woolliness in nectarines. Journal of Horticultural Science, Ashford, v. 64, n.1, p. 443-447, 1989.

VON MOLLENDORFF, L.J.; DE VILLIERS, O.T.; JACOBS, G.; WESTRAAD, I. Molecular characteristics of pectic constituents in relation to firmness, extractable juice, and woolliness in nectarines. Journal of the American Society for Horticultural Science, Alexandria, v. 118, n. 2, p. 77-80, 1993.

WATADA, A.; KO, N.; MINOTT, D. Factors affecting quality of fresh-cut horticultural products. Postharvest Biology and Technology, Wageningen, v. 9, n.2, p.115-125, 1996. 
ZHOU, H.; DONG, L.; BEN-ARIE, R.; LURIE, S. The role of ethylene in the prevention of chilling injury in nectarines. Journal of Plant Physiology, Lancaster, v. 158, n. 1, p. 55-61, 2001.

ZHOU, H.; LURIE, S.; LERS, A.; KHATCHITSKI, A.; SONEGO, L.; BEN-ARIE, R. Delayed storage and controlled atmosphere storage of nectarines: two strategies to prevent woolliness. Postharvest Biology and Technology, Wageningen, v. 18, n. 1, p. 133-141, 2000a.
ZHOU, H.; SONEGO, L.; KHALCHITSKI, A.; BEN-ARIE, R.; LERS, A.; LURIE, S. Cell wall enzymes and cell wall changes in 'Flavortop' nectarines: mRNA abundance, enzyme activity, and changes in pectic and neutral polymers during ripening and in woolly fruit. Journal of the American Society for Horticultural Science, Alexandria, v. 125, n.1, p. 630-637, 2000b.

ZOFFOLI, J.P.; ALDUNCE, J.R.P.; CRISOSTO, C.H. Modified atmosphere in fruits of Elegant Lady and Ohenry peaches. Postharvest News and Information, Amsterdam, v. 9, n.3, p. 1000-1005, 1998. 